\title{
薬物の生体膜輸送
}

\author{
高 野 幹 久
}

京都大学医学部附属病院薬剂部 焉 606-01 京都市左京区聖護院川原町 54

\section{Transport of Drugs in the Plasma Membranes}

\section{Mikihisa Takano}

Department of Pharmacy, Kyoto University Hospital, Faculty of Medicine, Kyoto University, Sakyo-ku, Kyoto 606-01, Japan

The present review is mainly concerned with the transport mechanisms of drugs in the plasma membranes of the renal epithelial cells. Organic anions and cations are actively secreted from plasma to filtrate in the proximal tubules. Studies with isolated membrane vesicles have generated a great deal of information about the transport mechanisms of organic ions in basolateral and brush-border membranes. p-Aminohippurate (PAH ; an organic anion) is actively transported in basolateral membranes by two functionally linked transport systems, $\mathrm{Na}^{+} /$dicarboxylate cotransporter and dicarboxylate/PA $\mathrm{H}$ exchanger. In rat brush-border membranes, $\mathrm{PAH}$ is probably transported by two distinct transport systems, anion exchanger and potential-sensitive transport system. On the other hand, tetraethylammonium (TEA ; an organic cation) is transported by a potential-sensitive, carrier-mediated system in basolateral membranes. In brush-border membranes, TEA is actively transported by $\mathrm{H}^{+} / \mathrm{TEA}^{\mathrm{A}}$ antiport system. Thus, the vesicle studies have provided new insights into our understanding of renal tubular transport mechanisms of drugs.

Key Words : kidney, active secretion, brush-border membrane, basolateral membrane, membrane vesicle, organic anion, organic cation

\section{1. はじめに}

生体膜を構築する脂質二重層は, 多くの物質に対しき わめて効率のよいバリアーとなる.このことは, 薬物に 対しても例外ではない. 医薬品 (薬物) が生体に投与さ れた場合, 吸収, 作用部位やその他の臓器への移行・分 布, 代謝, 排泄など様々な過程で生体膜とのかかわりを 持つ. 換言すれば, 薬物の生体膜透過性は上記の諸過程, ひいてはその薬物の生体内動態や薬効発現・毒性を支配 するきわめて重要な因子となる. 一般に, 薬物が生体膜
を透過する際には, その脂溶性によって透過することが 多い. すなわち, 単純拡散として分類される膜透過過程 である. 一方, 薬物が何らかの特殊なメカニズムによっ て, 膜を透過する例も数多く知られている. 薬物がある 種の特殊輸送系を介して生体膜輸送される場合, 大別し て次の二つのケースが考えられる.すなおち, 生体にとっ て必要な成分を輸送するために備わっている輸送系が, 薬物を “誤って” 基質として認識し輸送する場合，およ び生体によっての異物を体内から排除するために備わっ ている輸送系が, 生体異物である薬物を本来の基質とし 


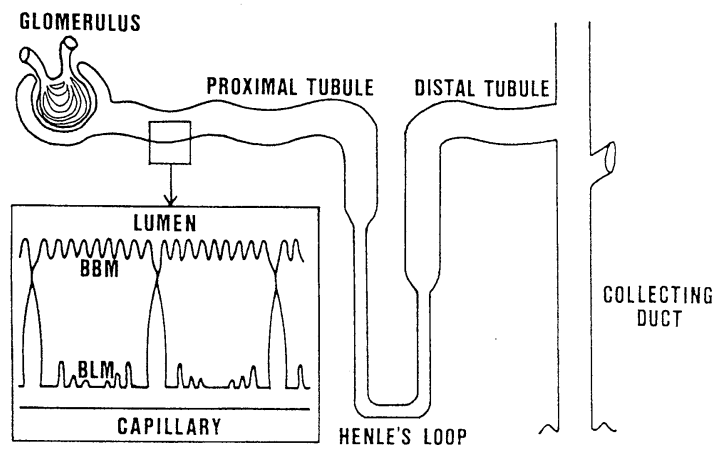

図 1. ネフロンおよび尿細管上皮細胞の模式図 BLM : basolateral membrane (側底膜) BBM : brush-border membrane (刷子縁膜)

て輸送する場合である．前者の例としては，小腸刷子縁 膜のジペプチド輸送系を介したセファロスポリン系抗生 物質（セファレキシン, セフラジン, セフィキシム, セ フチブテンなど) ${ }^{144}$, ベスタチン5), カプトプリル6) の輸送, リン酸輸送系を介したホスカルネット7),ホス ホマイシン ${ }^{8)}$ の輸送などがあげられる。一方, 後者の 例としては, 腎尿細管上皮細胞膜に存在する有機ア二オ ン, 有機力チオン能動排泄系があげられる。もちろん, これらの有機イオン輸送系によって輸送される内因性物 質も存在するが, 栄養物質輸送系に比べて有機イオン輸 送系の基質認識性は広く，さまざまな外因性物質やその 代謝物の体外排出を担っているものと考えられる. 本総 説では, 腎尿細管上皮細胞膜における有機アニオン, 有 機カチオン輸送を取り上げ, 薬物の生体膜輸送について 述べる.

\section{2. 薬物の腎挙動之その研究法}

腎臓はネフロンと呼ばれる構造・機能上の単位と血管 系から構成され ${ }^{9)}$, ネフロンは腎小体（糸球体及びボー マン囊）とそれに続く尿細管からなっている(図 1)。尿 生成の最初の段階は糸球体における血漿のろ過で, その 後, 糸球体ろ液が尿細管を下る間にさまざまな物質の再 吸収・分泌が行われる. 尿細管においては, 水, イオン, 栄養物質など生体にとって必要な物質の再吸収（尿細管 腔中から血管側へ), 薬物やその代謝物など生体にとっ て不要な，あるいは有害な物質の分泌（血管側から尿細 管腔へ）がきわめて巧妙に行われている。したがって, 薬物の腎挙動を把握するためには, 糸球体ろ過, 再吸収, 分泌というそれぞれの過程について明らかにする必要があ
る.

糸球体万過は加圧万過であり, ある物質がろ過を受け るか否かはその物質の分子サイズ, 荷電状態により決定 される．一般に薬物は比較的低分子のものが多く，血漿 蛋白之結合していない限りろ過されるものと考えてよ い. また, 薬物の再吸収は特殊な場合, すなわち先に述 べたように生体物質輸送系が薬物を基質として誤認識す る場合を除いて, 単純拡散によることが多い, 一方, 分 泌については能動的な過程であり, 特殊な薬物輸送系を 必要とする.

このような薬物分泌機構について研究するため, これ までに腎クリアランス法, ストップ・フロー法, 微小穿 刺法, 摘出腎灌流法, 腎皮質切片法などさまざまな方法 が駆使されてきた ${ }^{10)}$.これらの方法は, 分泌の有無, 尿 細管中の分泌部位などについて情報を得るために重要な 方法であるが, 詳細な膜輸送機構の解析は困難であった. こうした状況の中で, 膜小胞 (membrane vesicle) を 用いる実験法の開発は, 薬物の生体膜輸送機構の解明に 大きく貢献した ${ }^{11,12)}$.

腎尿細管上皮細胞は, 形態的・機能的に非対称性を示 し,管腔側の細胞膜之血管側の細胞膜は密着結合 (tight junction) の部分で区別される (図 1)。管腔側膜を刷子 縁膜 (brush-border membrane), 血管側膜を側底膜 (basolateral membrane) と呼ぶが, 両細胞膜ではそ の性質, 特に物質輸送機構や局在酵素が異なっている. 薬物の尿細管分泌は経上皮性の輸送過程であり, 側底膜 を介した血管側から細胞内一の取り込み，刷子縁膜を介 した細胞内から管腔中への放出という二つの膜透過過程 を必要とする.したがって薬物の能動分泌機構について 明らかにするには，それぞれの膜における輸送機構につ いて解析する必要がある，これを可能にしたのが，膜小 胞を用いた実験系の確立であった。

膜小胞系は，組織や細胞系に比べて次のような特長を 有している.

（1）極性を有する上皮細胞から刷子縁膜, 側底膜を分 離調製することによって，それぞれの膜における 物質輸送能を解析することができる.

（2）膜輸送の条件設定が任意にできる，たとえば，能 動輸送の駆動力 (driving force) を人工的に与え ることができる.

( 3 ) 細胞内代謝系による影響を除くことができる.

(4)細胞内成分との相互作用（結合など）を無視する ことができる. 


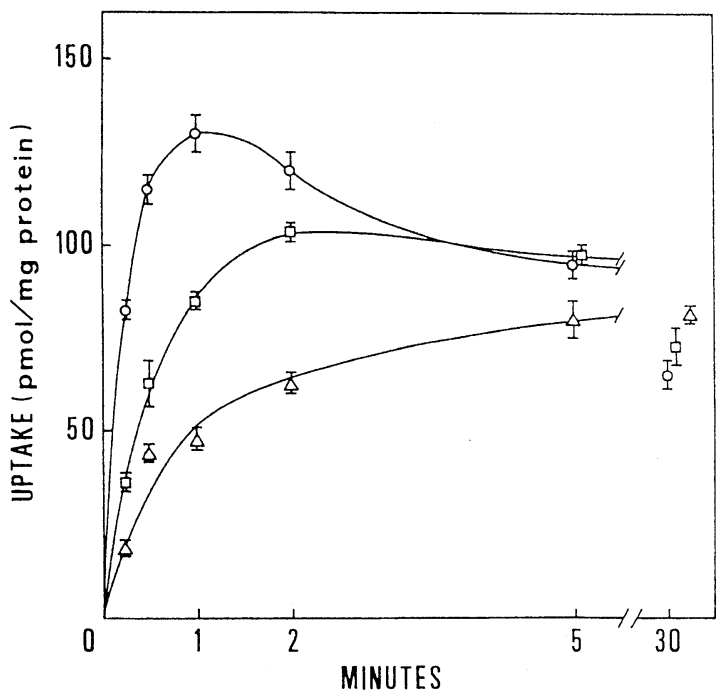

図 2. 刷子縁膜小胞による PAH 取り込みに及ぼ す無機アニオンの影響17)

膜小胞に非標識 $\mathrm{PAH}$ を負荷し, 標識体の 取り込みを種々の無機アニオン存在下で測定.

$\mathrm{O}: \mathrm{Cl}^{-} \square: \mathrm{SCN}^{-} \triangle: \mathrm{SO}_{4}{ }^{2-}$

刷子縁膜小胞の調製は, $\mathrm{Ca}^{2+}$ あるいは $\mathrm{Mg}^{2+}$ を用い た分別沈澱法によって調製されることが多い。この方法 の原理は, 多くの細胞内器官は二価カチオンと複合体を 形成して凝集・沈測するが，刷子縁膜は上清に残るとい う事実に基づいている，すなわち，刷子縁膜の表面負電 荷密度が, 側底膜や他の細胞内器官と比べて高いことを 利用した方法である。

一方, 側底膜は刷子縁膜と比重が似ていることもあり, その単離精製が困難であったが, Percoll 自己形成密度 勾配遠心法によって, よい純度のものが比較的短時間で 得られるようになった ${ }^{13)}$.こうして得られた刷子縁膜小 胞, 側底膜小胞を用いた輸送研究によって, 近位尿細管 における糖やアミノ酸の再吸収機序のみならず, 薬物の 能動分泌機構の解明も飛躍的に進展した.

\section{3. 有機アニオン輸送系}

腎臟の近位尿細管に有機アニオン輸送系が存在するこ とは古くから知られており, 多くのアニオン性薬物がこ の輸送系によって能動的に尿中排泄されることが報告さ れてきた. 有機アニオン輸送の機構解析に膜小胞系が初 めて用いられたのは, 1976 年, R. Kinne のグループに よってである ${ }^{14)}$ (なお, R. Kinne はその後も膜小胞系
による解析を中心に研究を進め, 腎臟におけるさまざ まな物質輸送機構を明らかにした功績により 1989 年の Homer W. Smith 賞を受賞した ${ }^{15)}$ )。筆者らの研究室 でも約 10 年ほじ前から刷子縁膜小胞および独自にその 調製法を確立した側底膜小胞を用い，薬物の膜輸送研究 に取り組んできた．ここではわれわれが得た知見を中心 に, 有機アニオンの輸送機構について述べる16,17).

\section{1 腎尿細管側底膜における有機アニオン輸送}

モデル薬物として代表的有機アニオンである ノ馬尿酸 (p-aminohippurate; PAH) を用い, 取り込 み実験は迅速ろ過法により行った. すなわち, 膜小胞と 基質を一定時間インキュベートしたのち, ミリポアフィ ルターでろ過し, 洗浄後小胞内に取り込まれた放射活性 を測定した．ラット腎側底膜小胞による PAH 取り込み の濃度依存性について調べたところ, 高濃度で飽和現象 が認められた。 また小胞内に非標識の $\mathrm{PAH}$ を負荷した のち, $\left[{ }^{3} \mathrm{H}\right] \mathrm{PAH}$ の取り込みを測定したところ, 顕著 な取り込み促進効果が認められた。これはキャリアーを 介する輸送に特徽的に観察される trans-stimulation （あるいは countertransport）効果によるものと考え られる.したがって, PAH は側底膜においてキャリ ア一輸送されることが明らかである.このことは, $\mathrm{PAH}$ 輸送の Arrhenius plot が約 $25^{\circ} \mathrm{C}$ で折れ曲がることと も符合する.

側底膜における $\mathrm{PAH}$ 輸送に及ぼす trans-stimulation 効果についてさらに詳細に検討した. 小胞内に負 荷する非標識 PAH の濃度を上げていった場合, $\left[{ }^{3} \mathrm{H}\right]$ $\mathrm{PAH}$ の取り込みはそれにともなって上昇し, $5 \mathrm{mM}$ 負 荷では見かけの上り坂輸送 (over shoot 現象) が認め られた。このような条件下で，無機アニオンの影響につ いて検討したところ, 側底膜における $\mathrm{PAH}$ 輸送の制御 因子としてクロライド $\left(\mathrm{Cl}^{-}\right)$が重要であることが判明し た. $\mathrm{Cl}^{-}$は濃度依存的に $\mathrm{PAH}$ の交換輸送活性を促進し, また, $\mathrm{Cl}^{-}$を他の無機アニオン, $\mathrm{SO}_{4}{ }^{2-}$ や $\mathrm{SCN}^{-}$で置き 換えた場合にはPAH の取り込みは低下した（図 2). $\mathrm{Cl}^{-}$の効果については, Pritchard ${ }^{18)}$ も認めているが その機構に関しては明らかではない，細胞外液中の $\mathrm{Cl}^{-}$ 濃度は約 $110 \mathrm{mM}$ であり, 側底膜を介した血管側から 細胞内への $\mathrm{PAH}$ 輸送に対し, 生理的濃度の $\mathrm{Cl}^{-}$が何 らかの形で活性調節因子として働いているものと思われ る.

側底膜における有機アニオン輸送の駆動力については 


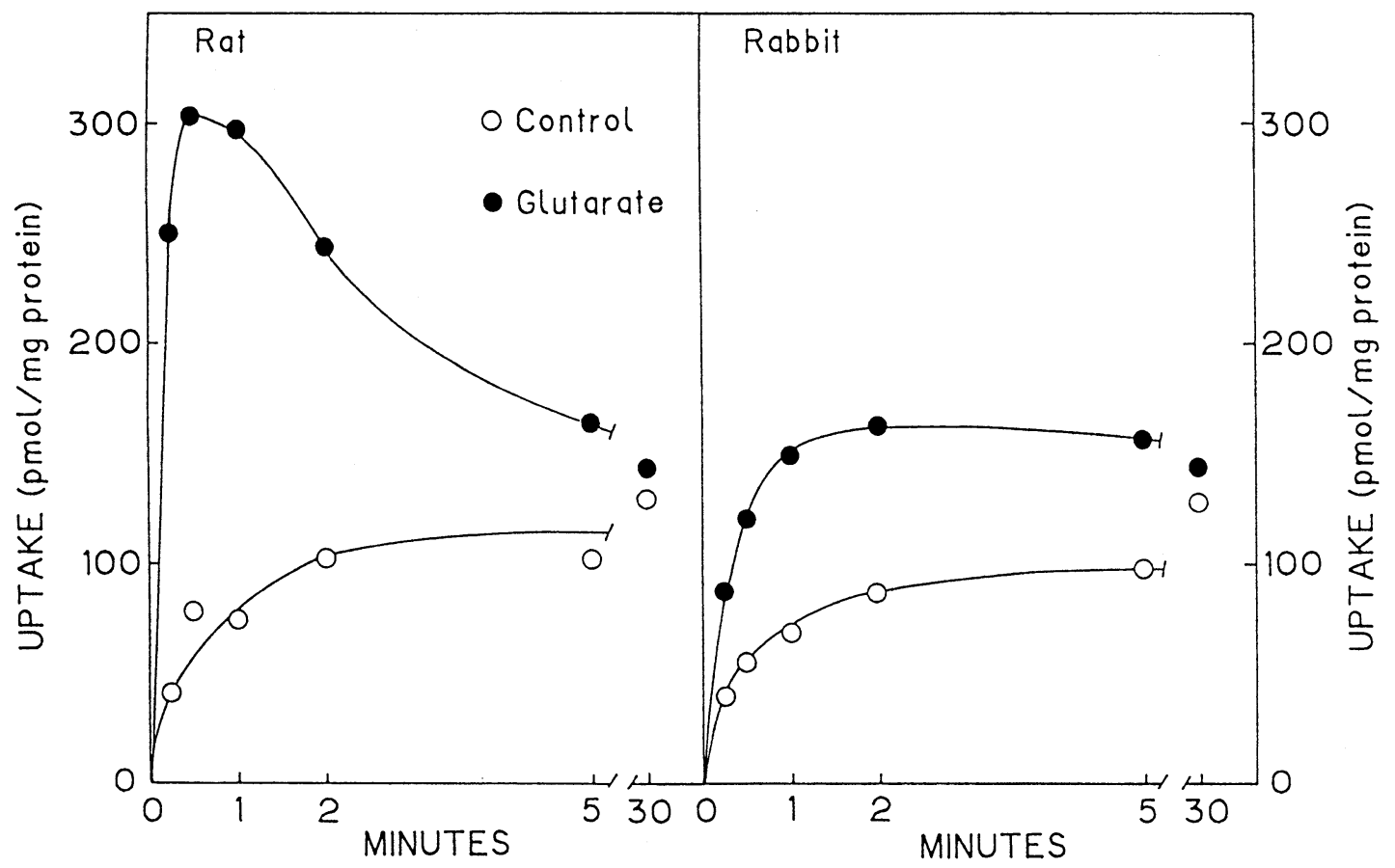

図 3. 側底膜小胞による PAH 取り込みに及ぼすグルタル酸の影響

$\mathrm{Na}^{+}$勾配 (小胞内く小胞外) 存在下において $10 \mu \mathrm{M}$ のグルタル酸を添加し, $\mathrm{PAH}$ 取り込みを測定.

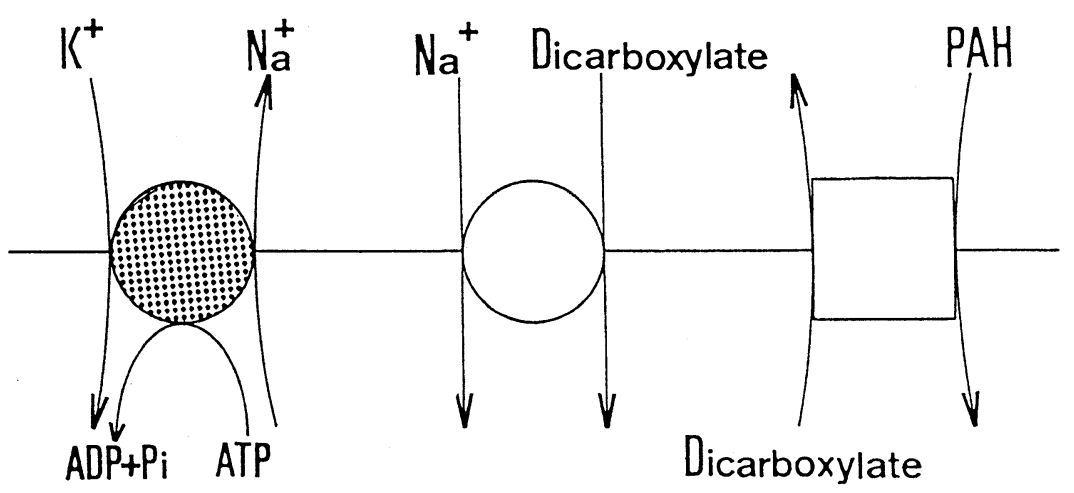

BLOOD

BASOLATERAL MEMBRANE

図 4. 腎尿細管側底膜における有機アニオン $(\mathrm{PAH})$ の輸送機構

長い間不明であり，特に $\mathrm{Na}^{+}$の役割については議論の 多いところであった. 上述したように, PAH の取り込 みは側底膜小胞内に非標識 PAH を負荷した場合, 促進 され overshoot 現象が認められる.このことは, もし 有機アニオン輸送系 (PAH輸送系) を介して輸送される ような内因性の物質が存在し, かつその物質が細胞内か ら血管側への濃度勾配を有するならば, in vivo におい
て PAH 輸送の駆動力となり得ることを意味する. 1987, 1988 年に二つのグループが, 膜小胞系を用いた実験か ら,この内因性基質はジカルボン酸であろうと報告し $た^{18.19)}$. すなわち, ラット側底膜小胞による $\mathrm{PAH} の$ 取り込みは, $\mathrm{Na}^{+}$勾配存在下においてジカルボン酸 （ $\alpha$ ーケトグルタル酸やグルタル酸）を添加した場合, 著 しく促進され overshoot 現象が認められた，側底膜に 


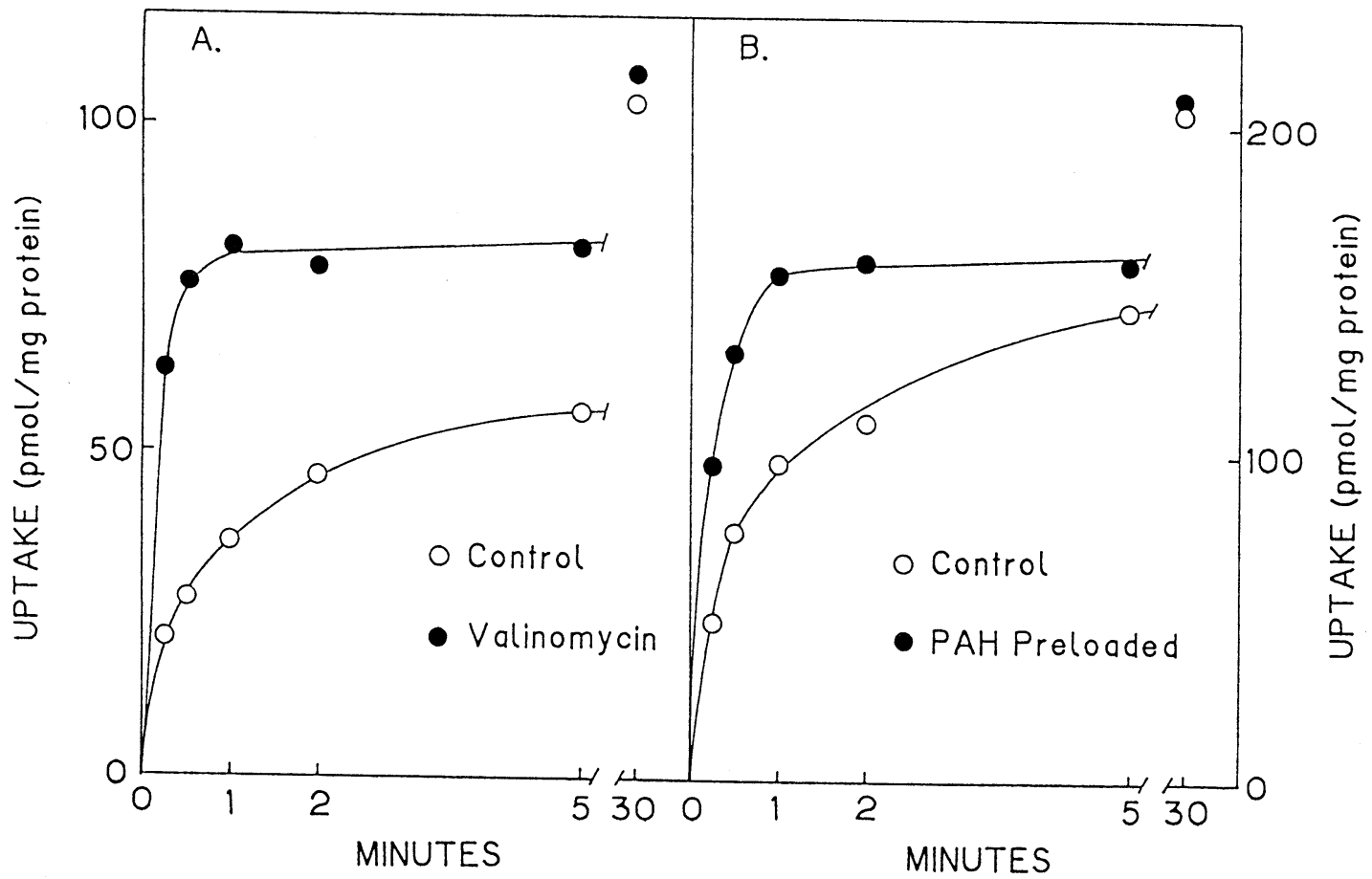

図 5. 刷子縁膜小胞による $\mathrm{PAH}$ の取り込み

A. 小胞内正の膜電位による取り込み促進効果

B. 非標識 PAH 負荷による取り込み促進 (trans-stimulation) 効果

おけるジカルボン酸輸送は, $\mathrm{Na}^{+}$勾配によって能動的 に駆動される( $\mathrm{Na}^{+} /$ジカルボン酸共輸送)。したがっ て, $\mathrm{Na}^{+}$勾配によって二次的に形成された外向きのシ カルボン酸勾配が, PAH の能動的な取り込みを引き起 こしたものと考えられる. われわれも，ラットならびに 家兔の腎側底膜小胞を用い，ジカルボン酸による PAH 取り込み促進効果を認めた (図 3). したがって, 側底膜に おける PAH の能動輸送は, (1) $\left(\mathrm{Na}^{+}+\mathrm{K}^{+}\right)-\mathrm{ATP}$ ase に よって $\mathrm{Na}^{+}$勾配(細胞外>細胞内)が形成される, (2) ジカ ルボン酸 (生体内においては $\alpha$-ケトグルタル酸)がN $\mathrm{a}^{+}$との共輸送により能動的に細胞内に取り込まれる,

(3) 血管側の PAH は細胞内のジカルボン酸との交換輸 送により能動的に細胞内に取り込まれる，ことにより達 成されるものと考えられる (図 4). この機構によるよ, $\mathrm{Na}^{+}$はジカルボン酸との共輸送に必要であるが直接 PAH 輸送を駆動するものではなく，これまでin vivo， in vitro を含め統一した見解が得られていなかった $\mathrm{Na}^{+}$ の役割についても, ある程度説明できる. 今後, このよ うな $\mathrm{PAH}$ 輸送機構が膜小胞系だけでなく生体内におい ても中心的役割を占めるのか，種差はあるのか，なよ゙を
明らかにする必要がある. それにしてもなぜ生体は, 有 機ア二オンの排泄のためにこのような複雑な機構を発達 させてきたのであろうか, 興味のあるところである.

\section{2 腎尿細管刷子縁膜における有機アニオン輸送}

ラット腎尿細管刷子縁膜小胞による PAH の取り込み は, アニオン輸送の阻害剂であるプロベネシドや 4, 4’diisothiocyano-2, 2'-disulfonic stilbene (DIDS) に よって阻害された. したがって, 刷子縁膜における $\mathrm{PAH}$ 輸送には, 何らかの特殊輸送系が関与するものと推察され る. また, PAH の取り込みに及ぼす膜電位の影響につい て膜透過性の異なる無機アニオンを用い検討したところ, その取り込みは相対的に小胞内正の膜電位によって促進さ れた.このことは, $\mathrm{PAH}$ の細胞内から管腔側への移行に 際し, 生理的な環境, すなわち管腔側正の膜電位が輸送の 駆動力として働く可能性を示している.

近年, 刷子縁膜における $\mathrm{PAH}$ 輸送は動物種によって 異なるとの報告がある.これまでのところイヌやラット では, PAH や尿酸のような有機アニオンのみならず, $\mathrm{Cl}^{-}, \mathrm{OH}^{-}, \mathrm{HCO}_{3}{ }^{-}$なよ゙の無機アニオンまでも基質とし 
て認識するアニオン交換輸送系が関与するという報告が 多(20,21).

一方, F. Roch-Ramel のグループは，家鬼やブタの 刷子縁膜にはこのようなア二オン交換輸送系は存在せ ず, 膜電位依存性の特殊輸送系が関与すると報告してい $ろ^{22.2{ }^{23}}$. 彼らは動物種によるこのようなアニオン輸送 機構の差異が, 尿酸の腎挙動に深くかかわっていると推 論している，すなわち，ラットやイヌなどアニオン交換 輸送系を有する動物では尿酸は再吸収され, 家兔やブ夕 などアニオン交換輸送系を持たず, 膜電位依存性の輸送 系のみが存在する動物では尿酸は分泌されるというもの である.

上述したようにわれわれはラット刷子縁膜において， 膜電位依存性の PAH 輸送過程が存在することを認めて いる. しかし，ラットにおいて膜電位依存性の輸送系が 存在するかどうかについては議論の分かれるところで あった，その原因の一つには，アニオン交換輸送系と膜 電位依存性輸送系の分離評価が困難であったことに起因 するものと思われる。，そこで，ラット刷子縁膜における $\mathrm{PAH}$ 輸送について, 二種の独立した輸送系が存在する か否かについて検討を加えた. ラット刷子縁膜小胞によ る $\mathrm{PAH}$ の取り込みは, 内向き $\mathrm{K}^{+}$勾配存在下でバリノ マイシンを添加し, 小胞内正の膜電位を形成させた場合, 顕著に促進された（図 5A)。この結果は, 膜透過性の異 なる無機アニオンを用いた検討結果と対応する．膜電位 による $\mathrm{PAH}$ 取り込み促進効果は, 膜内外の電位差が大 きくなるにつれて増大した，さらに，膜電位によって促 進された PAH 輸送は, プロベネシド, フロセミド, DI DSにより強く阻害された.

これらの結果から,ラット刷子縁膜における $\mathrm{PAH}$ 輸 送には, 膜電位依存性の特殊輸送系が存在することが明 らかである. 次に，アニオン交換輸送系との関連性につ いて検討した，われわれは当初，ラット刷子縁膜での PAH 輸送において, trans-stimulation 効果を認めな かった. しかしながらその実験は内向き $\mathrm{Cl}^{-}$勾配存在 下で行ったものであり, $\mathrm{Cl}^{-}$がアニオン交換輸送系の基 質となることを考えれば，こうした条件下ではアニオン 交換輸送 (この場合 $\mathrm{PAH} / \mathrm{PAH}$ 交換輸送) が抑制され た可能性がある. そこで $\mathrm{Cl}^{-}$非存在下で再検討したと ころ trans-stimulation 効果が認められ，アニオン交 換輸送系の存在を確認することができた (図 $5 \mathrm{~B}$ ). アニ オン交換輸送についても, 膜電位依存性輸送と同様に, 種々のアニオン輸送阻害剤に対し感受性であった. そこ
で，アニオン交換輸送系之膜電位依存性の関連性につい て明らかにするため，アニオン交換輸送に及ぼす膜電位 の影響について検討した，その結果，アニオン交換輸送 は膜電位非依存性の輸送過程であることが示唆された. これらの結果に基づき, われわれは現在, ラットの腎尿 細管刷子縁膜には二種類の独立した輸送系, すなわち膜 電位依存性輸送系とアニオン交換輸送系が存在するもの と考えている. それでは本当に, 家兔やブ夕の刷子縁膜 には膜電位依存性輸送系のみが存在し，アニオン交換輸 送系は存在しないのであろうか. 今後, $\mathrm{PAH}$ や尿酸の 経尿細管上皮輸送における両輸送系の寄与, 動物種によ る差異など，その生理的な役割も含め検討されなければ ならない。

\section{4. 有機カチオン輸送系}

腎臓の近位尿細管には，有機ア二オン輸送系とは別に 有機カチオン輸送系が存在し, カチオン性薬物の能動的 な分泌に重要な役割を果たしている。一般にカチオン性 薬物は強い薬理作用を有し, in vivo の輸送実験を行う ことが困難な場合が多い．また, in vitro 実験による情 報も乏しく，その機構に関しては不明な点が多かった. しかし, 有機カチオン輸送系の機構解析にも膜小胞系が 適用され，膜輸送における駆動力などが明らかになりつ つある，以下，側底膜および刷子縁膜の有機カチオン輸 送機構について，筆者らがこれまでに得た知見を中心に 紹介する $24 \sim 28$.

\section{1 腎尿細管側底膜における有機カチオン輸送}

基質として代表的有機カチオン，テトラエチルアンモ ニウム (tetraethylammonium; TEA) を用いた.ラッ 卜腎側底膜小胞による TEA の取り込みには, 濃度依存 性, trans-stimulation 効果および Arrhenius plot の 不連続性が認められ, キャリアー輸送系の寄与が明らか となった。

またTEA の取り込みは, $\mathrm{N}^{1}$-メチルニコチンアミド 等他の有機カチオンや塩化第二水銀によって阻害された が, 有機アニオン PAH では有意な阻害効果は認められ なかった. $\mathrm{K}^{+}$-バリノマイシンを用いて小胞内負の膜電 位を形成させたところ, TEA 取り込み促進効果が認め られた。したがって，側底膜を介した血管側から細胞内 への TEA 輸送には, 細胞内負の膜電位が駆動力として 働くものと考えられる. 刷子縁膜を介した細胞内から尿 

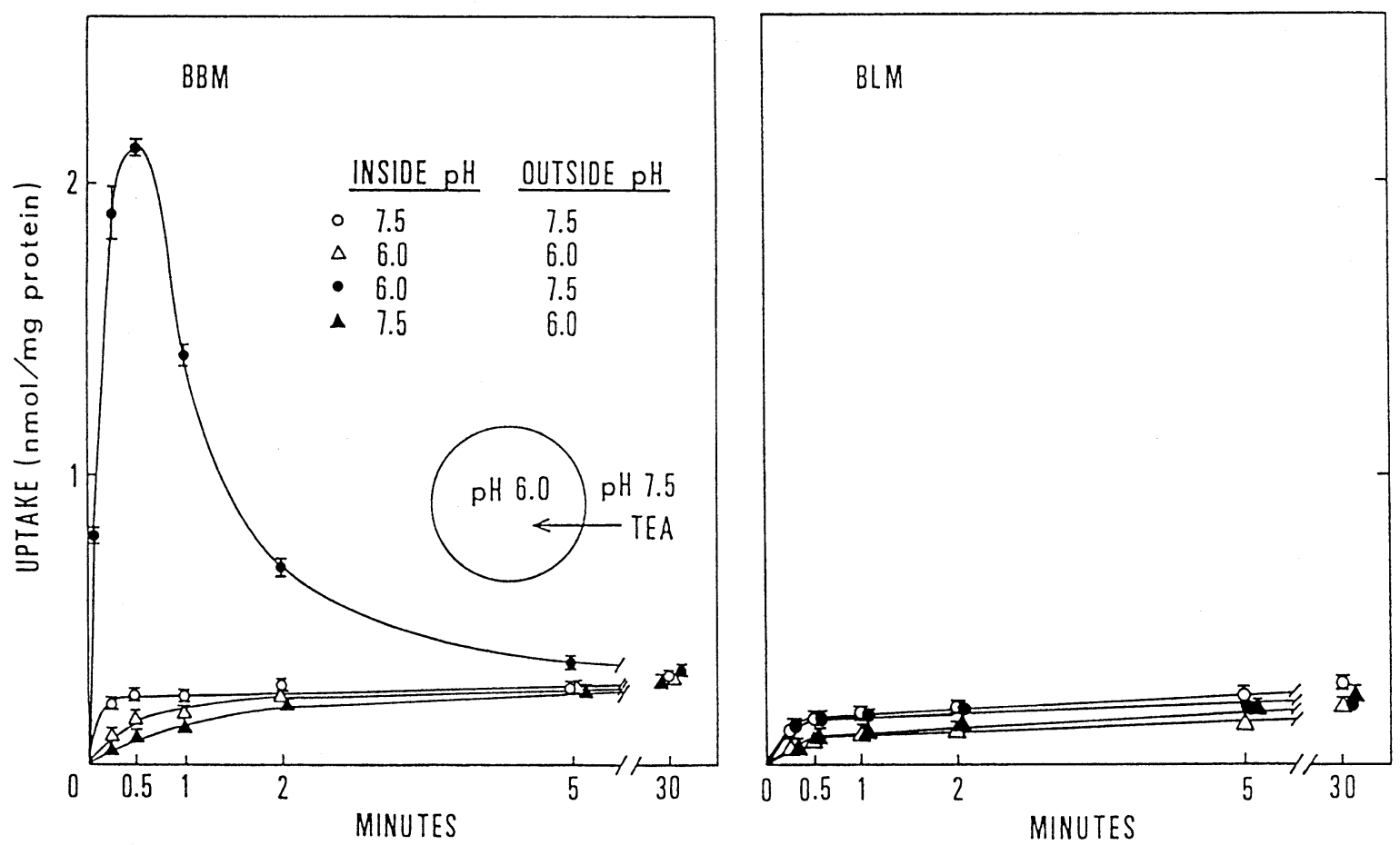

図 6. TEA 輸送に及ぼす $\mathrm{H}^{+}$勾配の影響 ${ }^{24}$

$\mathrm{BBM}$ : 刷子緣膜

細管腔中への有機アニオン輸送が，少なくとも一部，管 腔側正の膜電位によって駆動されることを考えあわせる と, 生体は細胞内外の電位差を巧妙に使って有機イオン を輸送していることが分かる.

近年, 側底膜における有機カチオン輸送には，カチオ ン交換輸送系が関与するとの報告がある ${ }^{29.30)}$. すなわ ち, コリン等の内因性有機カチオンとの対向輸送によっ て, 側底膜における有機カチオン輸送が駆動されるとす る考えである. しかし，コリンは細胞内での代謝が激し いこともあり, 細胞内から血管側への濃度勾配が存在す るかどうかは不明である. 側底膜における有機カチオン 輸送が能動的な輸送過程であるのかどうかも含め，まだ まだ明らかにされなければならない点が多く残されてい る.

\section{2 腎尿細管刷子縁膜における有機カチオン輸送} 刷子縁膜における TEA 輸送も, 側底膜の場合と同様, キャリアーを介する輸送である。すすなお, 濃度依存 性, trans-stimulation 効果および Arrhenius plot の 不連続性が認められる. TEA 輸送の駆動力について検 討するため, 種々の無機イオン存在下でその取り込みを
測定した。 その結果, 外向きの $\mathrm{Na}^{+}$勾配あるいは $\mathrm{Li}^{+}$ 勾配による TEA 取り込み促進効果を認めた。 アクリジ ンオレンジを用いた螢光消光法などの結果から, TEA 輸送に及ぼす $\mathrm{Na}^{+}$勾配の効果は直接的なものではなく, 刷子縁膜に存在する $\mathrm{Na}^{+} / \mathrm{H}^{+}$対向輸送系 $\left(\mathrm{Li}^{+}\right.$も基質之 なる）を介して形成された $\mathrm{H}^{+}$勾配によるものと推察さ れた。そこで，TEA 輸送に及ぼす $\mathrm{H}^{+}$勾配の影響につ いて検討したところ, 外向きの $\mathrm{H}^{+}$勾配 (小胞内 $\mathrm{pH} 6.0$, 小胞外 $\mathrm{pH}$ 7.5) を与えた場合, TEA の取り込みは著し く促進され，overshoot 現象が認められた（図 6)。一 方, 内向きの $\mathrm{H}^{+}$勾配存在下においては, きわめて低い 取り込みを示した．また，外向き $\mathrm{H}^{+}$勾配による TEA 取 り組み促進効果は，プロトノフォア FCCP (carbonyl cyanide p-trifluoromethoxyphenyl hydrazone) に よってほぼ完全に消失した。

これらの結果から, 刷子縁膜における TEA 輸送は, 基質と逆方向の $\mathrm{H}^{+}$勾配によって駆動される能動輸送系 $\left(\mathrm{H}^{+} / \mathrm{TEA}\right.$ 対向輸送系 $)$ であると結論された. in vivo においても $\mathrm{Na}^{+} / \mathrm{H}^{+}$対向輸送系の働きによって管腔側 酸性 (約 $0.5 \mathrm{pH}$ unit) の $\mathrm{H}^{+}$勾配が形成されていること から, 細胞内の有機カチオンは, この輸送系によって管 

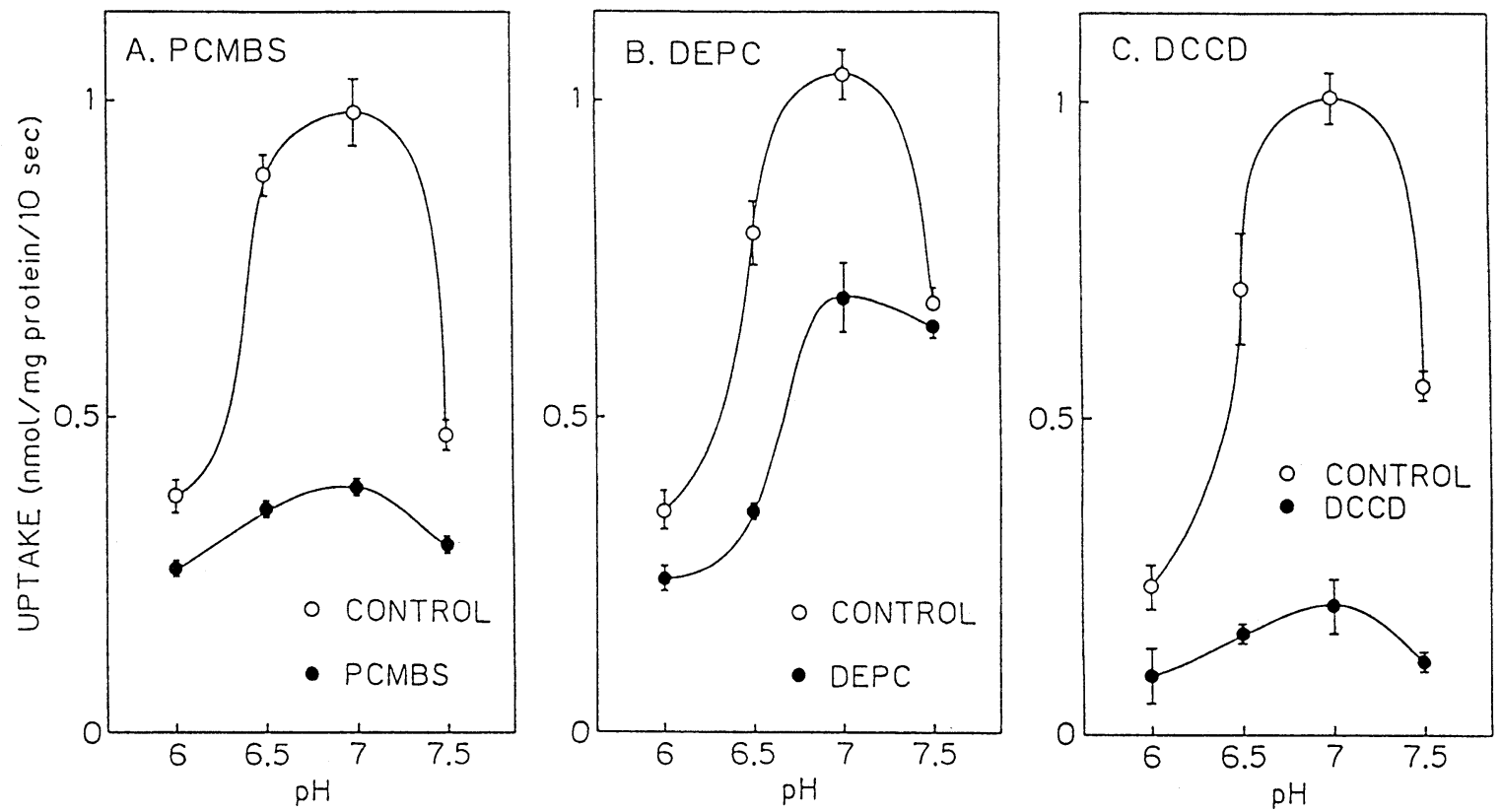

図 7. 刷子縁膜小胞による $\mathrm{pH}$ 依存性 TEA 取り込みに及ぼす化学修飾剤処理の影響

腔側へとくみ出されるものと考えられる，一般に動物細 胞における物質輸送（二次性能動輸送）は, $\mathrm{Na}^{+}$と共役 して輸送される場合が多い。しかし, $\mathrm{H}^{+} /$有機カチオン 対向輸送系以外にも，小腸や腎臓の刷子縁膜におけるジ ペプチド輸送のように $\mathrm{H}^{+}$と共役する例が見つかってき ており ${ }^{31}$ ３2)，生体におけるエネルギー利用を考える上 で興味深い。なお，側底膜小胞による TEA 取り込みに おいては， $\mathrm{H}^{+}$勾配の影響は認められなかった（図 6).

筆者らはさらに, 臨床上繁用されている医薬品, シメチ ジン (抗潰瘍薬) やセファレキシン, セフラジン（アミ ノー $\beta$-ラクタム抗生物質）等もこの輸送系を介して輸送 されることを明らかにした ${ }^{33.34)}$. 後者は，アミノ基と カルボキシル基を有する両性イオン型薬物である。この ように, $\mathrm{H}^{+}$/有機カチオン対向輸送系は幅広い基質認識 能を持ち，さまざまなイオン性薬物の尿細管分泌に寄与 しているもの之思われる.

輸送蛋白の機能と構造の関連性を解析する一方法とし て, 化学修飾試薬が用いられている，筆者らも刷子縁膜 を種々のアミノ酸残基修飾試薬で処理し, 有機カチオン 輸送に及ぼす影響について検討した。そ結果， $\mathrm{SH}$ 基 修飾剂 p-chloromercuribenzenesulfonate，ヒスチジ ン残基修飾剤 diethylpyrocarbonate (DEPC), カルボ キシル基修飾剤 N, N'-dicyclohexylcarbodiimide (DCCD) での処理によって TEA の取り込みは阻害さ
れた (図 7)。なお，DEPC 処理による TEA 取り込み 阻害効果は，取り込みを中・酸性の $\mathrm{pH}$ で測定した場合 にのみ認められ，アルカリ領域では影響が認められな かった。こうしたアミノ酸残基が TEA 輸送において, あるいは TEA と $\mathrm{H}^{+}$の共役過程においていかなる役 割を担っているのかは今後の検討課題である. 非機能残 基の修飾によっても輸送活性の低下がおこりうることは 考慮すべきであるが，現時点ではこうした情報を蓄積し ていくことも重要と考える.

刷子縁膜における TEA 輸送は， $\mathrm{H}^{+}$勾配のみならず $\mathrm{pH}$ 自身によっても著しい活性調節を受ける。すなわち， その活性を $\mathrm{H}^{+}$勾配非存在下で測定した場合, $\mathrm{pH} 7$ 付 近で最大輸送活性を示す. $\mathrm{pH}$ と TEA 輸送特性の関連 性について検討するため, 種々の $\mathrm{pH}$ における transstimulation 効果の機構解析を行った. その結果, $\mathrm{pH}$ 6.5，7.5，8.0では，いずれの $\mathrm{pH}$ においても transstimulation 効果が認められ, 見かけの overshoot 現 象が観察された. しかし, プロトノフォア FCCP を共存 させた場合, 各 $\mathrm{pH}$ で著しい差が認められた。すなわち, $\mathrm{pH} 6.5$ では FCCP の共存により trans-stimulation 効果がほぼ消失したのに対し, pH 8.0 では影響が認め られなかった(図 8，9)。pH 7.5 ではこの中間である. したがって, trans-stimulation 効果は, $\mathrm{pH}$ の低いと ころでは $\mathrm{H}^{+}$勾配の形成を介した二次的な効果であり, 

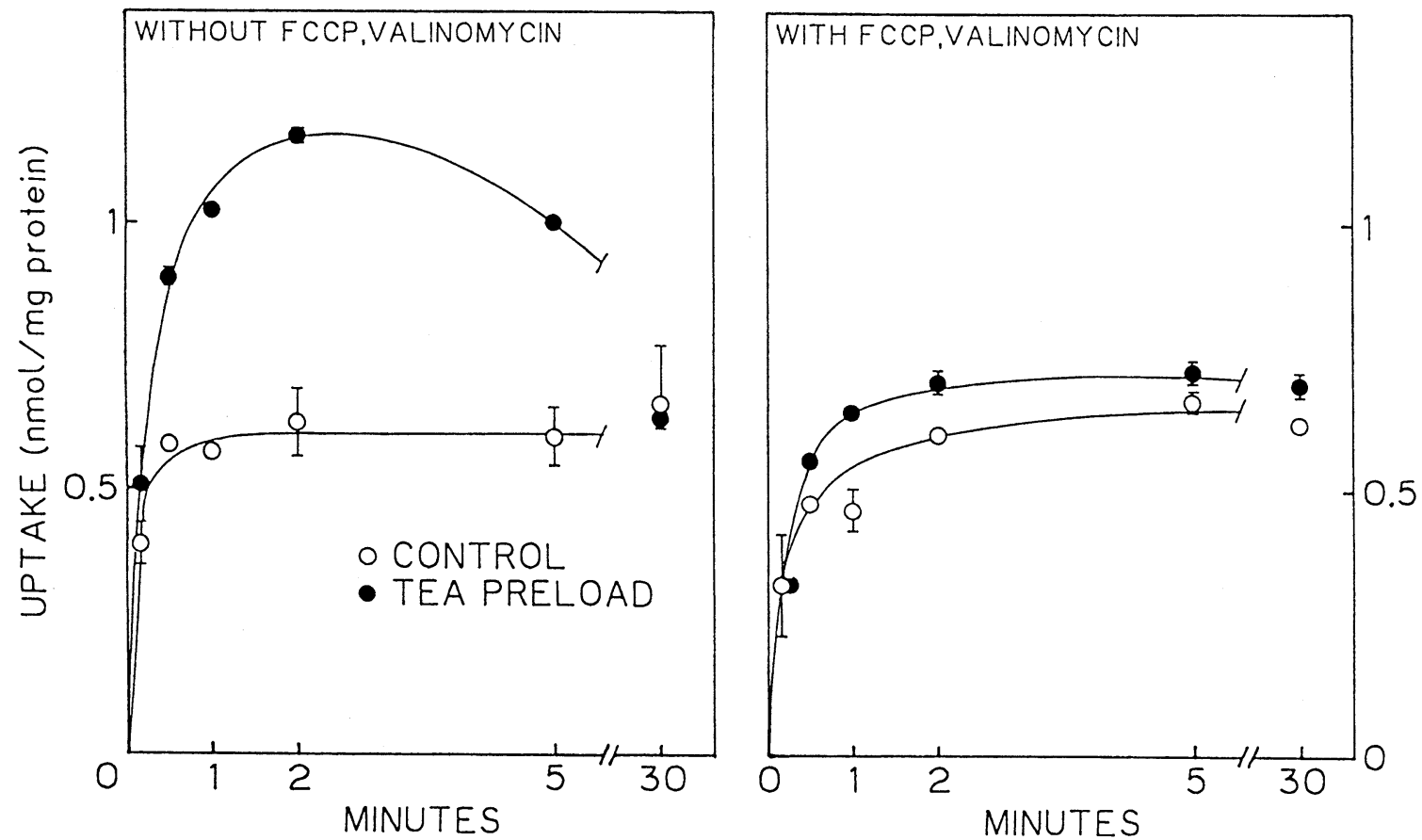

図 8. 刷子縁膜における TEA の trans-stimulation 効果に及ぼす FCCP の影響 (pH 6.5)
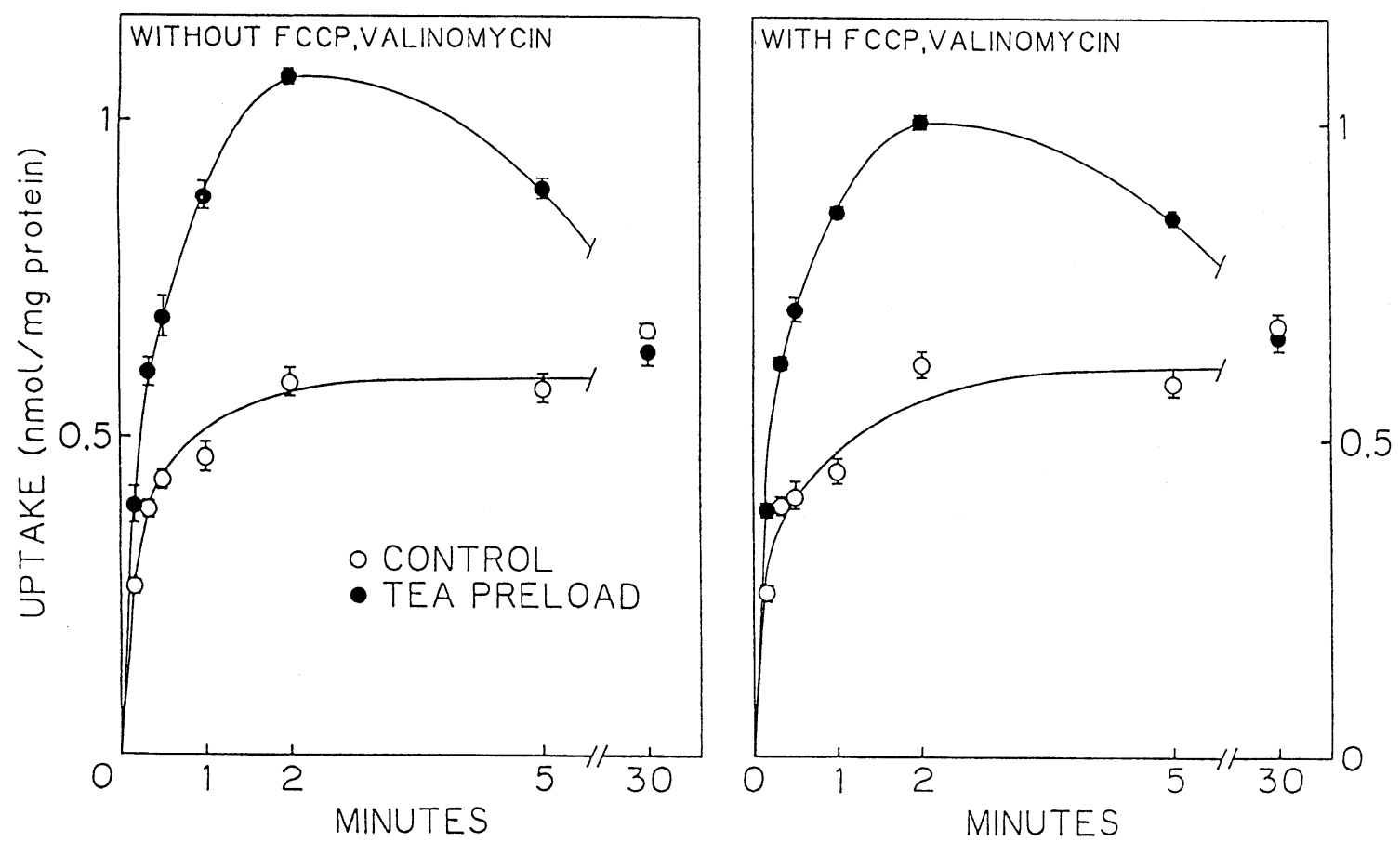

図 9. 刷子縁膜における TEA の trans-stimulation 効果に及ぼす FCCP の影響 $\left(\mathrm{pH} \mathrm{8.0)^{28) }}\right.$ 
一方, 高い $\mathrm{pH}$ 領域では TEA/TEA の直接交換反応に よるものと考えられる．上述のように，DEPC 処理の 効果も $\mathrm{pH}$ によって異なることを考えあわせると, $\mathrm{pH}$ の変化にともなって輸送活性のみならず輸送機構自身も 变化するのかも知れない。

\section{5. おわりに}

以上, 腎尿細管上皮細胞膜における有機アニオン, 有 機カチオン輸送系を中心に, 薬物の生体膜輸送について 述べてきた，薬物の膜輸送研究も，本質的には糖やアミ ノ酸などの栄養物質輸送研究と同様の流れで進展してい るように思われる．最近の傾向として，培養細胞を用い た薬物輸送研究の増加があげられる. 生体の機能を保持 した種々の株化細胞の樹立や経上皮細胞輸送研究のため の透過性フィルターシステム (Transwell など) が手軽 に入手できるようになったことなどがその原因と考えら れる，たとえば，培養腎上皮細胞 LLC-PK I (ブ夕腎由 来)や OK (フクロネズミ腎由来) は有機カチオン輸送活 性を保持していることが報告されており，TEA や N'メチルニコチンアミドなどの輸送研究に利用されてい る $^{35,36)}$.

また, ヒト大腸癌由来の Caco-2 細胞は, 分化にとも なって小腸上皮細胞様の性質を持つことが明らかになっ てきており, 薬物の消化管吸収のモデル系として有用之 思われる．細胞系を用いることによって，これまで膜小 胞系で得られた知見の細胞レベルでの検証に加え, 輸送 活性の発現調節など, 実験系の特長を生かした新しい情 報が得られるものと期待される.

近年の分子生物学の発展, 普及は薬物の膜輸送研究の 分野にもおよびつつある．特に，アフリカッメガエル卵 母細胞を用いた発現クローニング法は, E. M. Wright のグループが小腸 $\mathrm{Na} / \mathrm{D}$-glucose 共輸送体の遺伝子配 列の決定に成功して以来, 注目を集めている ${ }^{37)}$. 本法 の特長は, 輸送体の構造（部分アミノ酸配列）に関する 情報や特異的な抗体がなくても, 活性発現を追跡するこ とによって遺伝子配列を決定し得ることである，筆者ら の研究室でも, 腎皮質より調製した mRNA を注入し た卵母細胞において，有機カチオン TEA の輸送活性の 発現を認めている. 最終的にこれらイオン性薬物輸送体 の構造が決定されれば, これまでに明らかになった輸送 機構（機能）に関する情報とあわせることによって，そ の分子機構がより明確になるものと思われる.
膜 (MEMBRANE), No. 17 Vol. 3 (1992)

151

薬物の生体膜輸送研究は, きわめて学際的な研究領域 であり,こうした研究を通じて得られた知見は, 薬物療 法等に対し有益な情報を提供し得るものと思われる.同 時にさまざまなタイプの薬物輸送系について解析を進め ることにより, 膜輸送という現象の分子レベルでの理解 につながれば幸いである。

\section{参考文献}

1) T. Okano, K. Inui, M. Takano, R. Hori : Biochem. Pharmacol., 35, 1781 (1986)

2) T. Okano, K. Inui, H. Maegawa, M. Takano, R. Hori : J. Biol. Chem., 261, 14130 (1986)

3) K. Inui, T. Okano, H. Maegawa, M. Kato, M. Takano, R. Hori : J. Pharmacol. Exp. Ther., 247, 235 (1988)

4) N. Muranushi, T, Yoshikawa, M. Yoshida, T. Oguma, K. Hirano, H. Yamada: Pharm. Res., 6, 308 (1989)

5) Y. Tomita, T. Katsura, T. Okano, K. Inui, R. Hori: J. Pharmacol. Exp. Ther., 252, 859 (1990)

6) M. Hu, G. L. Amidon : J. Pharm. Sci., 77, 1007 (1988)

7) A. Tsuji, I. Tamai : Biochem. Pharmacol., 38, 1019 (1989)

8) T. Ishizawa, A. Tsuji, I. Tamai, T. Terasaki, K. Hosoi, S. Fukatsu : J. Pharmacobio-Dyn., 13, 292 (1990)

9) Renal Commission of IUPS : Am. J. Physiol., 254, F1 (1988)

10）乾 賢一, “生物薬剤学一最近の進歩”, 伊賀立二, 奥村勝彦 (編)，薬業時報社, 1989, pp. 275

11) H. Murer, P. Gmaj:Kidney Int., 30, 171 (1986)

12）堀了平, 乾 賢一, “膜学実験法”, 中垣正幸 (編)，喜多見書房, 1984, pp. 155

13) K. Inui, T. Okano, M. Takano, S. Kitazawa, R. Hori : Biochim. Biophys. Acta, 647, 150 (1981)

14) W. Berner, R. Kinne: Pflügers Arch., 361, 269 (1976)

15) R. K. H. Kinne : Am. J. Physiol., 260, F153 (1991)

16) R. Hori, M. Takano, T. Okano, S. Kitazawa, K. Inui: Biochim. Biophys. Acta, 692, 97 (1982)

17) K. Inui, M. Takano, T. Okano, R. Hori : Biochim. Biophys. Acta, 855, 425 (1986)

18) J. B. Pritchard : Am. J. Physiol., 255, F597 (1988)

19) H. Shimada, B. Moewes, G. Burckhardt : Am. J. Physiol., 253, F795 (1987)

20) S. E. Guggino, G. J. Martin, P. S. Aronson : Am. J. Physiol., 244, F612 (1983)

21) T. G.Steffens, P. D. Holohan, C. R. Ross : Am. J. Physiol., 256, F596 (1989) 
22) F. Martinez, M. Manganel, C. Montrose-Rafizadeh, D. Werner, F. Roch-Ramel : Am. J. Physiol., 258, F1145 (1990).

23) D. Werner, F. Martinez, F. Roch-Ramel : J. Pharmacol. Exp. Ther., 252, 792 (1990)

24) M. Takano, K. Inui, T. Okano, H. Saito, R. Hori : Biochim. Biophys. Acta, 773, 113 (1984)

25) R. Hori, H. Maegawa, T. Okano, M. Takano, K. Inui : J. Pharmacol. Exp. Ther., 241, 1010 (1987)

26) H. Maegawa, M. Kato, K. Inui, R. Hori : J. Biol. Chem., 263, 11150 (1988)

27) R. Hori, H. Maegawa, M. Kato, T. Katsura, K. Inui : J. Biol. Chem., 264, 12232 (1989)

28) T.Katsura, H. Maegawa, Y. Tomita, M. Takano, K. Inui, R. Hori : Am. J. Physiol., 261, F 774 (1991)

29) P. P. Sokol, T. D. McKinney : Am. J. Physiol., 258, F1599 (1990)
30) W. H. Dantzler, S. H. Wright, V. Chatsudthipong, O. H. Brokl : Am. J. Physiol., 261, F 386 (1991)

31) V. Canapathy, F. H. Leibach: J. Biol. Chem., 258, 14189 (1983)

32) N. Takuwa, T. Shimada, H. Matsumoto, T. Hoshi: Biochim. Biophys. Acta, 814, 186 (1985)

33) M. Takano, K. Inui, T. Okano, R. Hori : Life Sci., 37, 1579 (1985)

34) K. Inui, M. Takano, T. Okano, R. Hori : J. Pharmacol. Exp. Ther., 233, 181 (1985)

35) A-K. Fouda, C. Fauth, F. Roch-Ramel : J. Pharmacol. Exp. Ther., 252, 286 (1990)

36) G. Yuan, R. J. Ott, C. Salgado, K. M. Giacomini : J. Biol. Chem., 266, 8978 (1991)

37) M. A. Hediger, M. J. Coady, T. S. Ikeda, E. M. Wright : Nature, 330, 379 (1987)

（受付 1992 年 1 月 6 日）

\section{第 14 回糖質シンポジゥム予告 $(2)$}

会 期: 平成 4 年 7 月 31 日（金） 8月 1 日（土）

会 場 : 日本都市センター

主 催 : 日本糖質学会

共 催 : 日本生化学会 $\cdot$ 日本化学会・日本農芸化学会 $\cdot$ 日本薬学会・有機合成化学協会・日本飳 粉学会・日本発酵工学会・高分子学会・日本膜学会・日本栄養食糧学会

参加費：日本糖質学会正会員および共催学会正会員：4,000 円（当日 4,500 円）

日本糖質学会学生会員：2,000 円（当日 2,500 円）

一般: 4,500 円（当日 5,000 円）

日本糖質学会学生会員以外の学生 : 2,500 円（当日 3,000 円）

懇親会： 7 月 31 日 18 時 15 分より 8,000 円（当日 9,000 円）

要旨集 : 4,500 円（送料を含む，糖質学会会員には無料配布）

申込方法 : 参加登録料，懇親会会費，要旨集代金の内訳を明記の上 6 月 27 日（土）までに郵便 振替にて振込下さい.

口座番号 東京 1-653324

口座名 第 14 回糖質シンポジウム世話人会

連絡先：函 108 東京都港区白金 5-9-1

北里大学薬学部内

第 14 回糖質シンポジウム

世話人会代表 膳 昭之助

TEL 03-3444-6161（内） 3132

FAX 03-3442-5674

*宿泊：エース航空（株）（Tel 03-5800-0810, Fax 03-5800-0811 : 担当大野澤）宛斡旋を依頼 しましたのでご利用下さい. 